Review Paper

\title{
Economic Analysis of Arrivals and Prices of Pomegranate in Solapur District of Maharashtra
}

\author{
Kamble, A.T. ${ }^{1 *}$, Perke, D.S. ${ }^{2}$ and Sangeeta Kumari, S. ${ }^{3}$ \\ Department of Agricultural Economics, College of Agriculture, VNMKV, Parbhani, Maharashtra, India \\ *Corresponding author: ajinkyakamble2462@gmail.com (ORCID ID: 0000-0002-7831-8911)
}

Received: $22-09-2021$

Revised: 26-11-2021

Accepted: 11-12-2021

\begin{abstract}
The price behaviour of different agricultural commodities and the responsiveness of market arrivals to the price movement to reduce the gap in market arrival mark the need for analyzing the market arrivals and prices. This study is based on the secondary data of 15 years from 2005-06 to 2019-20 which was collected from APMC Solapur and APMC Pandharpur in Solapur district. For the analytical framework, the Exponential Regression Equation was used to study the trend in arrivals and prices. During the study period, in Solapur market, arrival was highest in August and the lowest in April. Pandharpur market observed maximum arrival in July whereas the lowest arrival in February. In terms of prices, Solapur market witnessed maximum price per quintal in September whereas minimum price per quintal in May. Pandharpur market recorded highest price per quintal of Pomegranate in February and the lowest price per quintal in November. During the study period, Solapur market witnessed highest positive growth rate whereas Pandharpur market reported a non-significant growth in terms of arrival among the selected markets. In terms of prices, Solapur market showed a positive and significant growth rate while Pandharpur market observed a negative and non-significant growth during the study period. The main season for arrivals of the pomegranate in both markets was from August to December.
\end{abstract}

\section{HIGHLIGHTS}

0 Solapur market witnessed positive growth rate in terms of arrival and prices.

0 Pandharpur market reported a non-significant growth in terms of arrival and prices.

Keywords: Trend, arrivals, prices, growth rate, Solapur, Pandharpur

In recent years, India's horticultural crop scenario has improved drastically. Horticulture production was just 145.8 million tonnes in 2001-02, which was significantly less than food grain production (212.9 million tonnes). By 2009-10 to 2011- 12 both were at par and by 2018-19 horticulture production continuously increased and were higher than the food grain production recording total production of 313.85 million tonnes while food grain production stood at 283.37 million tonnes (NHB, 2019).

During 2019-20, the total pomegranate acreage in India was 275 thousand hectares with a production of 3256 thousand tonnes and productivity of 11.84 $\mathrm{MT} / \mathrm{ha}$. The other top countries ranked after India are China (1.2 lakh ha and 12.0 lakh MT), Iran (0.75 lakh ha and 11.0 lakh MT) and Turkey (0.35 lakh ha and 2.2 lakh MT). The global pomegranate scenario indicates that India has the advantage to come up with promising pomegranate technologies for the benefit of the Indian population (NRCP, 2019).

India is one of the world's leading producer of pomegranate (Aware et al. 2019). In terms of production and acreage, Maharashtra ranks first in acreage under cultivation and production followed

How to cite this article: Kamble, A.T., Perke, D.S. and Sangeeta Kumari, S. (2021). Economic Analysis of Arrivals and Prices of Pomegranate in Solapur District of Maharashtra. Economic Affairs, 66(04): 659-663.

Source of Support: None; Conflict of Interest: None (C) $\oplus$ 
by Gujarat, Karnataka, Madhya Pradesh and Andhra Pradesh (Patel et al. 2018).

Table 1: State-wise area, production and productivity of Pomegranate in India (2017-2018)

\begin{tabular}{llll}
\hline States & $\begin{array}{l}\text { Area } \\
\text { (in ₹ 000 ha) }\end{array}$ & $\begin{array}{l}\text { Production } \\
\text { (in ₹ 000 } \\
\text { tonnes) }\end{array}$ & $\begin{array}{l}\text { Productivity } \\
\text { (in MT/ha) }\end{array}$ \\
\hline Maharashtra & 147.91 & 1789.46 & 12.10 \\
Gujarat & 30.51 & 461.75 & 15.13 \\
Karnataka & 25.97 & 268.23 & 10.33 \\
$\begin{array}{l}\text { Madhya } \\
\text { Pradesh }\end{array}$ & 9.68 & 114.27 & 11.81 \\
$\begin{array}{l}\text { Andhra } \\
\text { Pradesh }\end{array}$ & 9.47 & 139.02 & 14.69 \\
$\begin{array}{l}\text { Rajasthan } \\
\text { India }\end{array}$ & 4.44 & 26.58 & 5.99 \\
\hline
\end{tabular}

Source: NHB database.

In Maharashtra, Pomegranate is mainly cultivated in Solapur, Nashik, Sangli, Satara, Ahmednagar, Pune and to a limited extent in Osmanabad, Jalna, Beed, Aurangabad, Jalgaon and Dhule (Kharat et al. 2019). In Maharashtra, the flowering seasons of pomegranate are June-July (Mrig Bahar), SeptemberOctober (Hasta bahar) and February-March (Ambe bahar). As area and Production of Pomegranate are increasing significantly in Solapur district, the present study was undertaken to study the trends in arrivals and prices of Pomegranate in Solapur district of Maharashtra.

\section{MATERIALS AND METHODS}

The time series data on market arrivals and prices were collected over a period of 15 years from 2005-2006 to 2019-2020. In Solapur district, there are a total of 11 functioning Agricultural Produce Market Committee (APMC). The secondary data were collected from one major APMC that is APMC Solapur and the other from APMC Pandharpur. To derive a valuable conclusion from the study, data was analysed by using simple tabular analytical tools such as mean, frequencies, ratios, percentages and functional analysis such as trend and compound growth rate in market arrivals and prices. The analytical techniques employed in the study are explained in the following sections.

\section{Trend in market arrivals and prices}

Dhende et al. (2020) studied the trend in arrivals and prices of agricultural commodities using exponential form of equation. To estimate and examine the trends in market arrivals and prices, the following form of equation was utilised.

$$
Y=a \cdot b^{t}
$$

Where,

$$
\begin{aligned}
& Y=\text { Monthly arrivals/prices } \\
& a=\text { Constant } \\
& b=\text { Trend coefficient } \\
& t=\text { Time period }
\end{aligned}
$$

Annual compound growth rate (CGR) in percentage was calculated as,

$$
\operatorname{CGR}(\%)=(\text { Antilog of } b-1) \times 100
$$

To carry out accurate and efficient analysis and processing with regard to trend in arrivals and prices of Pomegranate, $\mathrm{R}$ statistical software which is a free software environment for statistical computing was employed.

\section{RESULTS AND DISCUSSION}

The main aim of the study was to analyze the trend in arrivals and prices of pomegranate in Solapur district.

\section{Trend in arrivals and prices of pomegranate}

Like other agricultural commodities, pomegranate is also a seasonal crop. But using crop regulation practices like bahar treatment, it is made available throughout the year in pomegranate growing areas. Monthly variation in arrivals pattern is usually observed in different markets which are eventually reflected in the price prevailing in the market.

Trend in arrivals and prices were examined to study the change in arrivals and prices over the period of time in Solapur and Pandharpur market using exponential regression model. Annual compound growth rate of arrivals and prices of pomegranate in both the selected APMC were also calculated. The time series data on monthly arrivals and prices of pomegranate covering the time period of fifteen years (2005-06 to 2019-20) was collected from APMC, Solapur and APMC Pandharpur.

The mean arrivals and prices of Pomegranate in the selected markets during the study period were 
Table 2: Market-wise monthly average of Arrivals and prices of Pomegranate (2005-06 to 2019-20)

\begin{tabular}{llllll}
\hline \multirow{2}{*}{ S1. No. } & Month & \multicolumn{2}{c}{ Solapur } & \multicolumn{2}{c}{ Pandharpur } \\
\cline { 3 - 6 } & & Monthly Average & $\begin{array}{l}\text { Monthly Average } \\
\text { Price (₹/q) }\end{array}$ & $\begin{array}{l}\text { Monthly Average } \\
\text { (q) }\end{array}$ & $\begin{array}{l}\text { Monthly Average } \\
\text { Price (₹/q) }\end{array}$ \\
\hline 1 & January & 104233.94 & 1812.03 & 4450.47 & 4451.09 \\
2 & February & 108866.27 & 1958.12 & 3621.13 & 4857.60 \\
3 & March & 79556.54 & 2038.54 & 4572.67 & 4715.32 \\
4 & April & 75745.47 & 1821.10 & 5294.13 & 4400.49 \\
5 & May & 92271.34 & 1675.86 & 4009 & 3800.55 \\
6 & June & 147387 & 1694.69 & 5304.34 & 3763.30 \\
7 & July & 224238.4 & 1831.58 & 8790.34 & 4006.93 \\
8 & August & 293400.67 & 2226.33 & 8511.34 & 4213.73 \\
9 & September & 196414.07 & 2480.49 & 6733.9 & 4445.52 \\
10 & October & 117437.27 & 2400.15 & 4325.34 & 4323.31 \\
11 & November & 125914.34 & 2415.31 & 3769 & 3718.73 \\
12 & December & 134782.07 & 2107.49 & 4756.74 & 4341.96 \\
\hline
\end{tabular}

Note: Simple average was used to find out monthly average.

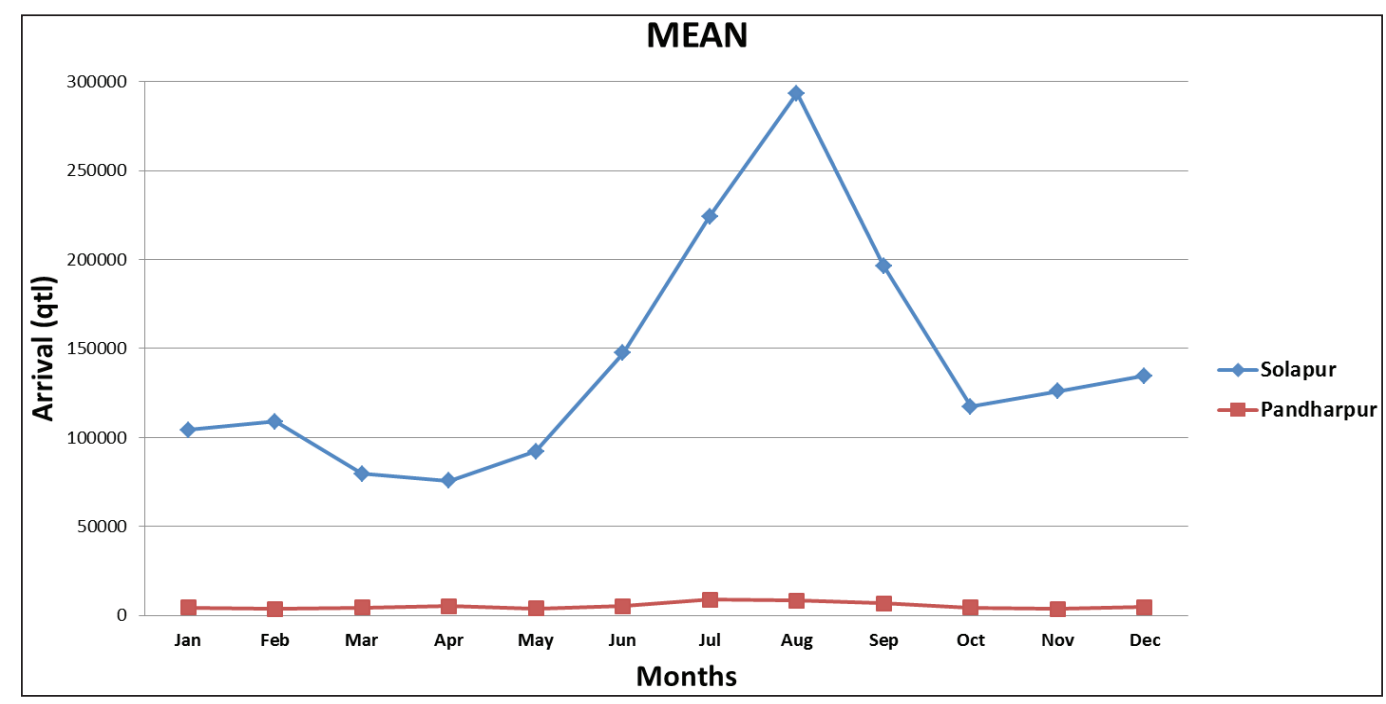

Fig. 1: Graphical representation of Mean of arrivals of Pomegranate in Solapur and Pandharpur market

worked out to examine the trend and the results are presented in Table 2. The results in Table 2 revealed that during the study period, in Solapur market, arrivals were highest in the month of August (293400.67 quintals) as majority of the farmers harvest and bring their produce to the market by mid July while lowest arrivals were recorded in the month of April (75745.47 quintals). Likewise, Pandharpur market observed maximum arrival in the month of July (8790.34 quintals) whereas lowest arrival was observed in the month of February (3621.13 quintals). The results are in correlation with the findings of Ali et al. (2018).

The variation in arrivals strongly reflected the price movement in both the market. In Solapur market, the maximum price per quintal was in the month of September (₹ 2480.49/q) whereas minimum price per quintal was in the month of May (₹ 1675.86/q). Pandharpur market showed highest price per quintal during offseason i.e. in the month of February (₹ 4857.60/q) due to decrease in arrivals in the market and lowest price per quintal in the month of November (₹ 3718.73/q).

\section{Pomegranate Arrivals}

Annual Compound Growth Rate with respect to arrival was calculated for Solapur APMC and Pandharpur APMC and the results are presented in Table 3. 


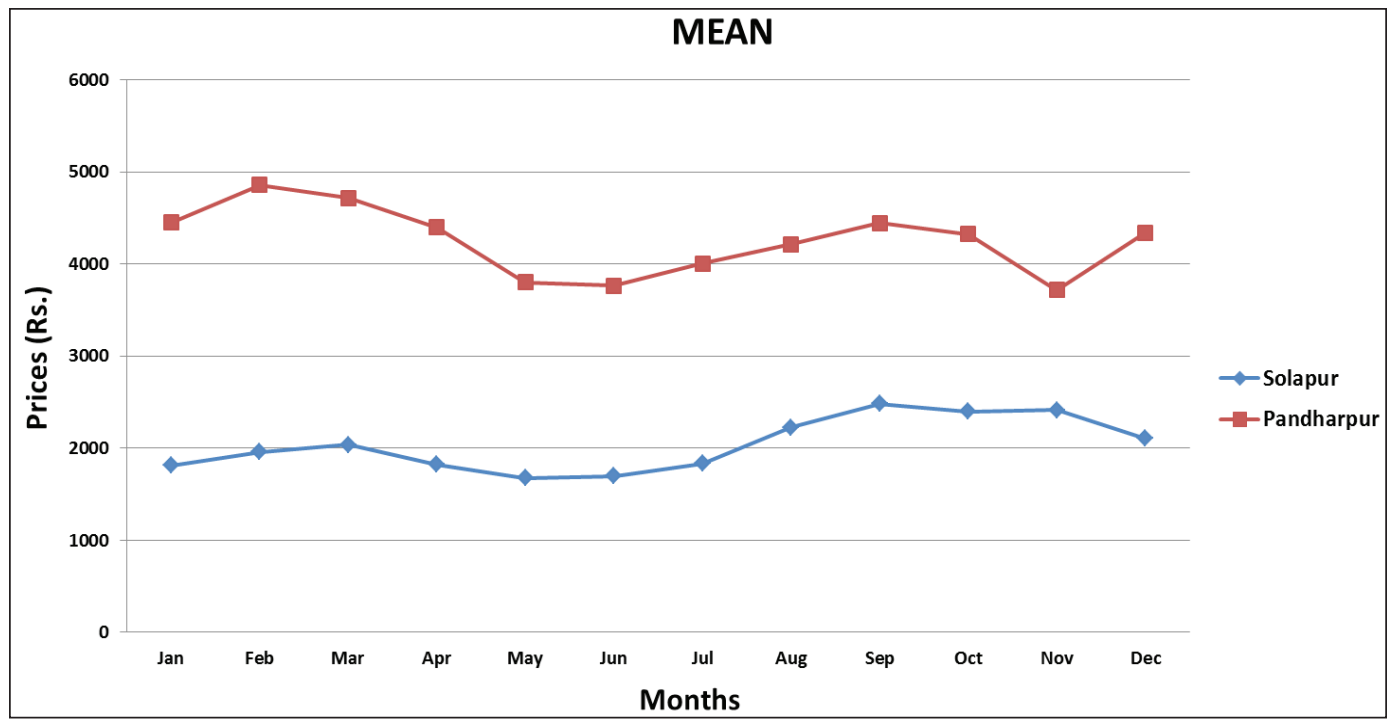

Fig. 2: Graphical representation of Mean of prices of Pomegranate in Solapur and Pandharpur market

Table 3: Marketwise compound growth rate of arrivals of Pomegranate

\begin{tabular}{lll}
\hline Particulars & Solapur & Pandharpur \\
\hline $\mathrm{A}$ & 11.43 & 8.435 \\
$\mathrm{~B}$ & 0.054 & 0.016 \\
$\mathrm{R}^{2}$ & 0.223 & 0.039 \\
t-value & 1.69 & 0.64 \\
CGR & $5.58^{*}$ & 1.65 \\
\hline
\end{tabular}

* denotes significance at $10 \%$ level of significance.

The results revealed that both Solapur and Pandharpur market showed positive growth rate with respect to arrivals during the study period. Among both the markets, highest growth rate was observed in Solapur market with compound growth rate at 5.58 per cent per annum at ten per cent level of significance. In Pandharpur market, arrivals recorded a compound growth rate of 1.65 per cent per annum which was statistically non-significant. The results are in close association with the findings of Naidu \& Kumari (2013).

\section{Pomegranate Prices}

Annual Compound Growth Rate with respect to price was calculated for Solapur APMC and Pandharpur APMC and the results are presented in Table 4.

Table 4 revealed that price in Solapur market witnessed a compound growth rate of 2.54 per cent per annum which was statistically significant at five per cent level of significance.
Table 4: Marketwise compound growth rate of prices of Pomegranate

\begin{tabular}{lll}
\hline Particulars & Solapur & Pandharpur \\
\hline A & 7.45 & 8.42 \\
B & 0.025 & -0.01 \\
$\mathrm{R}^{2}$ & 0.42 & 0.172 \\
t-value & 2.69 & -1.44 \\
CGR & $2.54^{* *}$ & -0.996 \\
\hline
\end{tabular}

** denotes significant at $5 \%$ level of significance.

While negative and non- significant growth rate of -0.966 per cent was observed in Pandharpur market. Similar findings were reported in the study conducted by Saha et al. (2020).

\section{CONCLUSION}

The present study in Solapur district concluded that in Solapur and Pandarpur market, the highest arrivals of pomegranate fruit were in the month of August and July, respectively and lowest arrivals were observed in the month of April and February, respectively. The price of Pomegranate in Solapur market was recorded to be highest in the month of September and lowest in the month of May whereas Pandharpur market witnessed highest prices in the month of July and lowest prices in the month of February. Analysis of the growth rate of arrivals and prices of pomegranate in the selected markets of the study area suggested that Solapur market recorded positive and significant growth rate annually whereas Pandharpur market witnessed 
a non-significant growth during the study period. With respect to pomegranate price, Solapur market registered positive and significant growth rate while Pandharpur market showed a negative and non-significant growth during the overall period of study.

\section{REFERENCES}

Ali, J., Kachroo, J., Bhat, D.J. and Bhat, A. 2018. Analysis of Prices and Arrivals of Apple Fruit in Narwal Market of Jammu. Eco. Affairs, 63(1): 107-111.

NHB. 2019. Annual reports. Available at: www.nhb.gov.in. (Last Assessed on: 11 ${ }^{\text {th }}$ December, 2020).

Aware, M.R., Perke, D.S. and Yannam, P. 2019. Trend and Competitiveness of Pomegranate in domestic and International Prices. Int. J. Recent Sci. Res., 10(09): 3478134783.

Dhende, A.A., Suryawanshi, R.R., Patil, R.A. and Shinde, H.R. 2020. Trends in arrivals and prices of selected agricultural commodities in APMC, Sangli. Int. J. Chem. Stud., 8(6): 2676-2678.
Kharat, P.B., Chavan, R.V., Deshmukh, K.V. and Wagh, S.S. 2019. Economics of Marketing of Pomegranate in Solapur District of Maharashtra. Int. J. Recent Sci. Res., 10(9): 34636-34639.

Naidu, G.M. and Kumari, V.M. 2013. Time series analysis of arrivals and prices of castor in Kurnool district of Andhra Pradesh, Bioinfolet., 10(4B): 1379-1381.

Patel, R.M., Patel, R.R. and Patel, A.S. 2018. Price spread and market margin of pomegranate in Banaskantha district of North Gujarat. Gujarat J. Ext. Educ., (Special Issue on National Seminar): 143-150.

NRCP. 2019. National Research Centre on Pomegranate. Available at: www.nrcpomegranate.icar.gov.in. (Last Assessed on: 24 ${ }^{\text {th }}$ January, 2021).

Saha, N., Kar, A., Jha, G.K., Venkatesh, P. and Kumar, P. 2020. Market Arrival and Price Behaviour Analysis of Potato in Four Major Markets in India. Eco. Affairs, 65(4): 529-533. 
